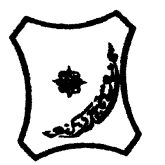

Bayero Journal of Pure and Applied Sciences, 11(1): 295 - 300

ISSN 2006 - 6996

\title{
EFFECT OF CROPPING SYSTEM INDUCED SHADING ON THE GRAIN YIELD AND YIELD ATTRIBUTES OF COWPEA VARIETIES INTERCROPPED WITH SORGHUM BASED SYSTEMS IN THE SUDAN SAVANNAH ECOLOGICAL ZONE OF NIGERIA
}

\author{
Nuhu, ${ }^{* 1} Y$. Mukhtar, ${ }^{2}$ F. B. Mohammed ${ }^{3}$ I. B. and Abdu ${ }^{4}$ L.S. \\ ${ }^{1}$ Department of Plant Biology Bayero University Kano, \\ ${ }^{2}$ Federal University Dutse and ${ }^{3}$ International Institute of Tropical Agriculture Kano, Nigeria. \\ ${ }^{*}$ Correspondence author:yusufnuhu2085@gmail.com.
}

\section{ABSTRACT}

Six cowpea varieties (IT98K-131-1, IT04K-227-4, IT89KD-288, IT93K-452-1, IT97K-499-35 and IT99K-573-1-1) were intercropped with a local sorghum (Kaura) using four row arrangements $(1 C: 1 S, 2 C: 2 S$, Mixed crop and sole) in field experiments conducted at IITA Minjibir Farm and research farm of the Faculty of Agriculture Bayero University Kano located in the Sudan Savannah ecological zone of Nigeria during the 2015 and 2016 rainy seasons. In the field, the experiment was laid in a randomized complete block design (RCBD). Analysis of variance (ANOVA) showed significant difference on cowpea cropping systems and variety on the yield and yield attributes. Grain yield of cowpea was significantly higher at $2 C: 2 S(663.0 \mathrm{~g})$ and sole $(1323.8 \mathrm{~g})$ row arrangements in both seasons, the highest grain yield was obtained in one early variety IT97K-499-35(650.5g) and three medium varieties, IT99K573-1-1(1060g), ITO4K-227-4 (983.7g) and IT98K-131-1 (870.5g) as tolerant shading varieties. However, the late maturing variety-IT89KD-288 recorded the lowest grain yield and is considered to be susceptible to shading. Results of correlation coefficient showed that among the growth characters, a significant number of branches recorded positive correlation with yield $(r=0.38)$ and 100 grain weight $(r=0.32)$.

Key words: Cropping systems, Cowpea varieties Grain yield, Intercropping and Shading.

\section{INTRODUCTION}

Shading reduces the amount of solar radiation reaching the plants. Steindler et al., (2007) reported that shading corm for 21 days during the reproductive phase was more detrimental to grain production per plant than shading for longer periods during vegetative and maturation phases. Plants shaded at $60 \%$ or higher during the reproductive phase had a full complement of normal leaves but initiated and developed only a limited number of kernels. Innis (2000), found that shading soybeans for as little as 5 or 10 days could reduce the seed yield over 15\% compared to the un shaded peanut.

\section{MATERIALS AND METHODS}

The field experiments were carried out at IITA farm in Minjibir Local Government Area, Kano State which has $12^{\circ} 10^{\prime} 42^{\prime \prime} \mathrm{N}$ latitude and $8^{\circ} 39^{\prime}$ 33" E longitudes and the research farm of Faculty of Agriculture, Bayero University Kano which has latitude of $11.5901^{\circ} \mathrm{N}$ and longitude of $8.2587^{\circ} \mathrm{E}$ in 2015 and 2016 rainy season. One local variety of sorghum popularly known as Red Kaura was collected from Institute for Agricultural Research, Kano and six cowpea varieties were collected from IITA Kano station. These comprised of two erect IT93K452-1 and IT98K131-1, two semi erect IT97K-499-35 and IT04K227-4 and two Spreading types IT99K-573-1-1 and IT89KD-288. The fields planting were conducted on 19th and 20th July 2015 for the first experiment and 18th June through 27th June 2016 for the second experiment respectively at IITA Farm Minjibir and Bayero University farm. Three cowpea seeds were sown per hole and were later thinned to two seedlings at three weeks after sowing; also three seeds of sorghum were intercropped with cowpea at 75 by $30 \mathrm{~cm}$ for $1 \mathrm{C}: 1 \mathrm{~S}$ and $2 \mathrm{C}: 2 \mathrm{~S}$ row arrangement and 75 by $20 \mathrm{~cm}$ for legume/cereal while for mixed crop it was 75 by $60 \mathrm{~cm}$ spacing. 
Special Conference Edition, November, 2018

The experiment was laid out in Randomize Complete Block Design (RCBD) with three replications. Number of pods, seed weight and 100-seed weight per plot were taken and average recorded while pod dry weight was recorded at physiological maturity using J. M. Electronic scale $510 \mathrm{~g} / 0.01 \mathrm{~g}$ sensitive balance. At harvest, all the pods from each plot were threshed weighed and yield determined in $\mathrm{kg} / \mathrm{ha}$.

\section{RESULTS}

Grain yield of cowpea was significantly affected by cropping system and cowpea variety in the two years and the combined analysis (Table1). At BUK farm in both 2015 and 2016 and the combined, the sole arrangement significantly out yielded other treatments with mixed crop recording the least values in the three cases while 1C:1S and 2C:2S being at par except in 2016 when 2C:2S had greater value over 1C:1S. At BUK farm, IT99K-573-1-1 and IT04K-227-4 had the significant and out yielded grain followed by IT98K-131-1 and IT93K-452-1 while the lowest grain yield was recorded by IT89KD-288. A similar pattern of response was recorded in the combined analysis in 2015. A significant interaction between cropping system and cowpea variety was recorded in the combined analysis, (Table 2). Varieties IT04K-227-4 and IT99K-573-1-
1 had the heavier grain yields at sole row arrangement. For IT89KD-288 grain yield was not affected by cropping system.

At Minjibir, grain yield of cowpea was significantly affected by cropping system and cowpea variety in the two years and the combined analysis (Table1). At Minjibir in 2015 sole had significantly out yielded the other treatments, but in 2016 it was 1C:1S and 2C:2S row arrangements that had the significantly larger grain. In the combined, sole arrangement showed no significant but heavier grain yield. At Minjibir in 2015, IT99K-573-1-1 out yielded the other varieties while IT97K-499-35and IT98K-1311 had similar values. In 2016 the effect of cowpea variety was not significant on grain yield. However, the effect was significant in the combined analysis where IT99K-573-1-1, IT97K499-35, IT98K-131-1 and IT93K-452-1 had the greatest grain yield and variety IT89KD-288 also had the smallest grain yield. A significant interaction between cropping system and cowpea variety was recorded in the combined analysis (Table 2), varieties IT04K-227-4 and IT99K-573-11 had the greater grain yields at sole row arrangement. For IT89KD-288 grain yield was not affected by cropping system.

Table 1: Effect of Cropping System and Variety on Grain Yield Kg/ha of Cowpea at BUK and Minjibir, 2015, 2016 and Combined.

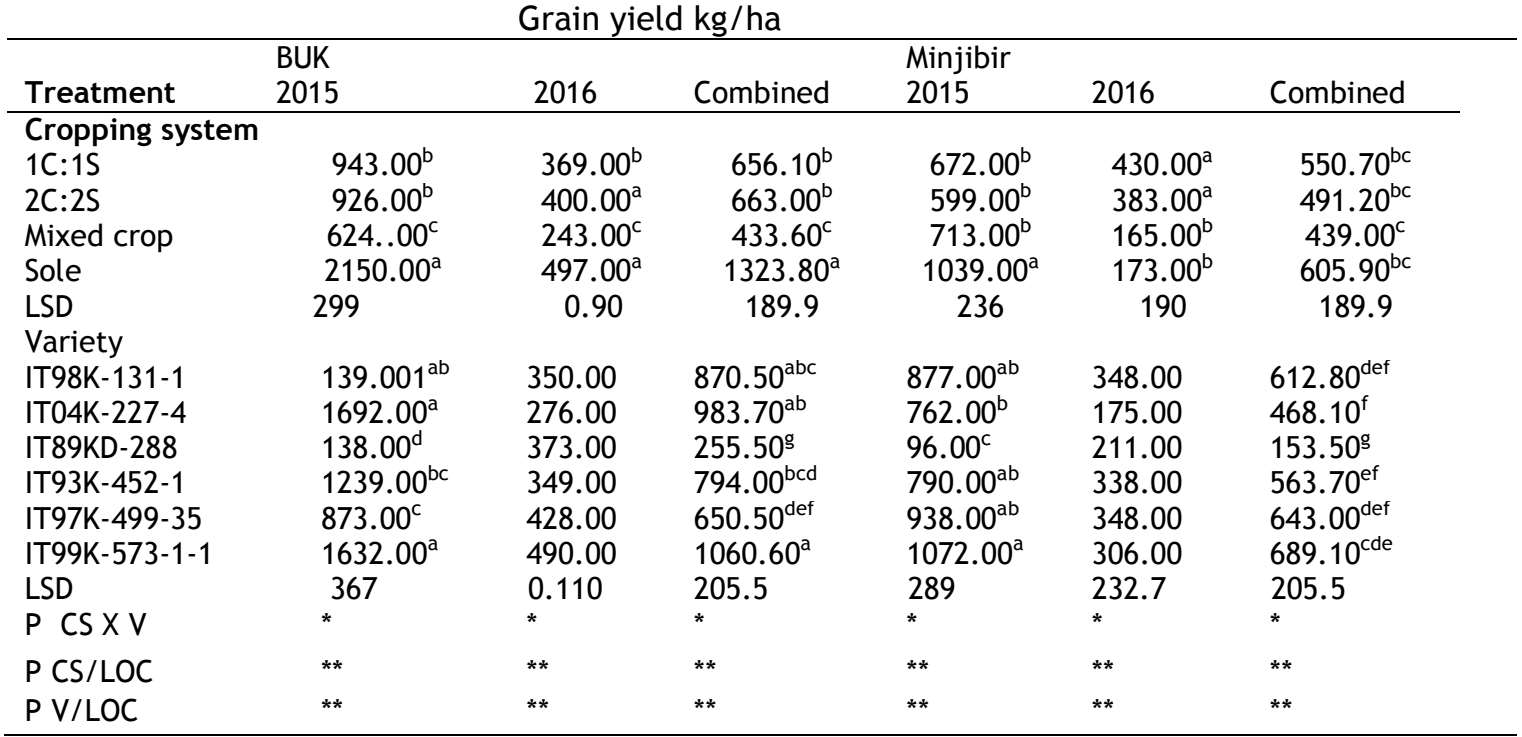

Means followed by the same letters(superscript) in a column are not significantly different using LSD at 5\% level of probability Key * -Significant at $1 \%$

**- Significant at $5 \%$

$1 \mathrm{C}: 1 \mathrm{~S}$ - One cowpea to One sorghum ratio

2C:2S -Two cowpea to Two sorghum ratio

Mixed crop- Two or more crops on the same ridge

Sole- Control or single crop

LSD- Least Significant Difference 
Special Conference Edition, November, 2018

Table 2: Interactive Effect of Cropping System and Variety on Grain Yield Kg/ha of Cowpea at BUK and Minjibir, 2015 and 2016 Combined.

\begin{tabular}{|c|c|c|c|c|}
\hline \multirow[b]{2}{*}{$\begin{array}{l}\text { Treatment } \\
\text { Variety }\end{array}$} & \multicolumn{4}{|c|}{ Cropping system } \\
\hline & 1C:1S & $2 C: 2 S$ & Mixed crop & Sole \\
\hline IT98K-131-1 & $753.40^{\text {cde }}$ & $517.10^{d-g}$ & $464.60^{e^{-j}}$ & $1231.60^{\mathrm{ab}}$ \\
\hline IT04K-227-4 & $683.10^{c-f}$ & $479.90^{e-i}$ & $401.30^{f-j}$ & $1339.40^{\mathrm{a}}$ \\
\hline IT89KD-288 & $198.10^{\text {hij }}$ & $193.90^{\mathrm{hj}}$ & $238.50^{g-j}$ & $187.40^{\mathrm{ij}}$ \\
\hline IT93K-452-1 & $564.90^{\text {def }}$ & $638.90^{\text {def }}$ & $546.20^{\text {def }}$ & $965.40^{\mathrm{bc}}$ \\
\hline IT97K-499-35 & $624.70^{\text {def }}$ & $688.70^{c-f}$ & $477.10^{e-j}$ & $796.40^{\text {cd }}$ \\
\hline IT99K-573-1-1 & $796.10^{\text {cd }}$ & $944.40^{\mathrm{bc}}$ & $490.10^{e-h}$ & $1268.90^{\mathrm{a}}$ \\
\hline LSD & & 298.0 & & \\
\hline $\mathrm{PCS} / \mathrm{V}$ & * & $*$ & * & * \\
\hline
\end{tabular}

Means followed by the same letters (superscript) in a column are not significantly different using LSD at $5 \%$ level of probability

Key * -Significant at $1 \%$

**- Significant at $5 \%$

$1 \mathrm{C}: 1 \mathrm{~S}$ - One cowpea to one sorghum ratio

2C:2S -Two cowpea to two sorghum ratio

Mixed crop- Two or more crops on the same ridge

Sole- Control or single crop

LSD- Least Significant Difference

P CS/V -Level of probability on cropping system and variety

Yield and Yield attributes combined at BUK and Minjibir Farms

The effects of cropping system and cowpea variety on 100-seed weight at BUK farm in 2015 and 2016 and the combined are shown in (Table 3). Cropping system at BUK had significant effect on 100-seed weight of cowpea in 2015 and the combined only with sole having the greatest value $(37.58 \mathrm{~g})$. Cowpea variety had significant effect on 100-seed weight in 2015, 2016 and the combined analysis. In 2015, IT99K-573-1-1 had the bigger seeds $(46.18 \mathrm{~g})$ while the smaller seeds were recorded by IT89KD-288(12.27g). In 2016, only IT89KD-288 and IT97K-499-35 had statistically smaller seeds compared with the other varieties which were not significantly different. However, in the combined, only IT99K573-1 was superior to others which were significantly different. In the combined analysis however, IT99K-573-1-1 had greater and significant 100-seeds weight over the other varieties. The interaction between the cropping system and the variety on 100-seed weight was significant and greater with IT99K-573-1-1 (Table 4).

The effect of cropping system and cowpea variety on 100-seed weight at Minjibir in 2015 and 2016 and the combined are presented in (Table 3). At Minjibir in both years and the combined, cropping system did not affect 100 seed weight. The effect of cowpea variety was significant in 2016 and the combined. In 2016, IT98K-131-1, IT04K-227-4 and IT99K-573-1-1 had similar and larger values over the other varieties with IT89KD-288 having the smallest seeds. In the combined analysis however, IT99K-573-1-1 had greater and significant 100 -seeds weight over the other varieties. The interaction between the cropping system and the variety on 100 -seed weight was significant and greater with IT99K573-1-1 across periods of study (Table 4 ). 
Special Conference Edition, November, 2018

Table 3: Effect of Cropping System and Variety on 100 Seed Weight of Cowpea at BUK and Minjibir, 2015 and 2016 Combined.

\begin{tabular}{lccllll}
\multicolumn{7}{c}{ 100 seed weight } \\
\hline Treatment & BUK & & & Minjibir \\
& 2015 & 2016 & COMBINED & 2015 & 2016 & COMBINED \\
\hline Cropping system & & & & & & \\
1C:1S & $33.94^{\mathrm{ab}}$ & 26.40 & 30.17 & 19.20 & 25.29 & 22.25 \\
2C:2S & $32.74^{\mathrm{b}}$ & 26.67 & 29.71 & 19.20 & 24.87 & 22.03 \\
Mixed crop & $30.78^{\mathrm{b}}$ & 25.52 & 28.15 & 20.26 & 23.43 & 21.84 \\
Sole & $37.58^{\mathrm{a}}$ & 29.43 & 33.51 & 21.84 & 28.83 & 25.34 \\
LSD & 4.73 & 5.04 & 3.74 & 4.47 & 5.23 & 3.74 \\
& & & & & & \\
Variety & & & & & & \\
IT98K-131-1 & $38.37^{\mathrm{b}}$ & $28.70^{\mathrm{a}}$ & $33.54^{\mathrm{bc}}$ & 22.71 & $29.13^{\mathrm{ab}}$ & $25.92^{\mathrm{de}}$ \\
IT04K-227-4 & $35.84^{\mathrm{b}}$ & $32.33^{\mathrm{a}}$ & $34.09^{\mathrm{b}}$ & 20.22 & $30.63^{\mathrm{ab}}$ & $25.43^{\mathrm{de}}$ \\
IT89KD-288 & $12.27^{\mathrm{c}}$ & $15.17^{\mathrm{c}}$ & $13.72^{\mathrm{g}}$ & 15.04 & $14.89^{\mathrm{d}}$ & $14.97^{\mathrm{g}}$ \\
IT93K452-1 & $33.04^{\mathrm{b}}$ & $31.10^{\mathrm{a}}$ & $32.07^{\mathrm{bc}}$ & 19.18 & $24.99^{\mathrm{bc}}$ & $22.09^{\mathrm{et}}$ \\
IT97K499-35 & $36.86^{\mathrm{b}}$ & $22.21^{\mathrm{b}}$ & $29.54^{\mathrm{cd}}$ & 19.66 & $22.37^{\mathrm{c}}$ & $21.02^{\mathrm{f}}$ \\
IT99K-573-1-1 & $46.18^{\mathrm{a}}$ & $32.49^{\mathrm{a}}$ & $39.34^{\mathrm{a}}$ & 23.94 & $31.60^{\mathrm{a}}$ & $27.77^{\mathrm{d}}$ \\
LSD & 5.79 & 6.17 & 4.20 & 5.47 & 6.41 & 4.20 \\
P CV*V & $* *$ & $* *$ & $* *$ & $* *$ & $* *$ & $* *$ \\
P CS/LOC & NS & NS & NS & NS & NS & NS \\
PV/LOC & $* *$ & $* *$ & $* *$ & $* *$ & $* *$ & $*$
\end{tabular}

Means followed by the same letters (superscript) in a column are not significantly different using LSD at $5 \%$ level of probability

Key * -Significant at $1 \%$

**- Significant at $5 \%$

$1 \mathrm{C}: 1 \mathrm{~S}$ - One cowpea to one sorghum ratio

2C:2S -Two cowpea to two sorghum ratio

Mixed crop- Two or more crops on the same ridge

Sole- Control or single crop

LSD- Least Significant Difference

Table 4: Interactive Effect of Cropping System and Variety on 100 Seed Weight of Cowpea at BUK and Minjibir, 2015 and 2016 Combined.

\begin{tabular}{|c|c|c|c|c|}
\hline Treatment & & opping sy & & \\
\hline Variety & $1 \mathrm{C}: 1 \mathrm{~S}$ & $2 C: 2 S$ & Mixed crop & Sole \\
\hline IT98K-131-1 & $28.67^{d-i}$ & $23.19^{i j k}$ & $28.43^{d-i}$ & $38.63^{\mathrm{a}}$ \\
\hline IT04K-227-4 & $31.17^{b-f}$ & $30.87^{\mathrm{b}-\mathrm{g}}$ & $27.10^{\mathrm{d}-\mathrm{i}}$ & $29.89^{c-h}$ \\
\hline IT89KD-288 & $9.59^{1}$ & $7.19^{l}$ & $17.10^{k}$ & $23.49^{n-k}$ \\
\hline IT93K-452-1 & $27.88^{\mathrm{d}-\mathrm{i}}$ & $24.43^{\mathrm{g}-\mathrm{j}}$ & $26.16^{\dagger-1}$ & $29.84^{c-h}$ \\
\hline IT97K-499-35 & $26.66^{\mathrm{e}-1}$ & $32.84^{\mathrm{a}-\mathrm{e}}$ & $22.46^{\mathrm{ijk}}$ & $19.15^{\mathrm{j}}$ \\
\hline IT99K-573-1-1 & $33.27^{\mathrm{a}-\mathrm{d}}$ & $36.69^{\mathrm{ab}}$ & $28.73^{\mathrm{d}-\mathrm{i}}$ & $35.52^{\mathrm{abc}}$ \\
\hline LSD & & 6.5 & & \\
\hline$P C S \times V$ & * & * & * & * \\
\hline
\end{tabular}

Means followed by the same letters (superscript) in a column are not significantly different using LSD at $5 \%$ level of probability

Key * -Significant at $1 \%$

**- Significant at $5 \%$

1C:1S- One cowpea to one sorghum ratio

2C:2S -Two cowpea to two sorghum ratio

Mixed crop- Two or more crops on the same ridge

Sole- Control or single crop

LSD- Least Significant Difference 
The results of combined correlation coefficient on the growth and yield of cowpea varieties intercrop with sorghum in 2015 and 2016 at BUK and Minjibir farms

Correlation coefficient between yield, growth and other characters of cowpea (Intercropped with sorghum) for the combined analysis are presented in (Table 5). All the characters studied were found to be significantly and positively correlated with grain yield except chlorophyll and stomata index. The association between 100 seed weight and other characters were examined, and it was observed that the association was significant and positive with all the characters except fodder, leaf area index, number of branches, number of leaves and dry fodder weight. Pod weight recorded highly significant and positive correlation with other characters except number of leaf and chlorophyll.
Dry fodder weight was significantly correlated with other characters except number of leaf. Chlorophyll was significantly correlated with other characters except fodder, leaf area index, light interception, number of branches, number of leaves and grain yield. Stomata index was significantly and positively correlated with leaf area, light interception and number of leaves. However, its association with fodder, leaf area index, number of branches and yield was negative. Number of leaves was only significantly and positively correlated with number of branches while the associations with other characters were negative. Number of branches was significantly and positively correlated with fodder, leaf area index, leaf area and light interception. Similarly, light interception was significantly and positively correlated with fodder, leaf area index and leaf area.

Table 4: Correlation Coefficient on growth and yield of Cowpea Varieties at BUK and Minjibir 2015 and 2016 wet season

\begin{tabular}{|c|c|c|c|c|c|c|c|c|c|c|c|c|}
\hline & Podwt & 100 sw & Chlp & dryfwt & Stomaidx & Yldkg/ha & Nlf6WAS & Nbrnch & Lghtr6WAS & Larea & LAI6WAS & FdyKgha \\
\hline PODWTPLT & 1.0000 & & & & & & & & & & & \\
\hline SEED100WT & $0.2411^{*}$ & 1.0000 & & & & & & & & & & \\
\hline Xphyll6WAS & -0.048 & $0.3286^{*}$ & 1.0000 & & & & & & & & & \\
\hline dryfodderwt & $0.4248^{*}$ & -0.1047 & $-0.2309^{*}$ & 1.0000 & & & & & & & & \\
\hline stomaidx6WAS & -0.0828 & $0.2985^{*}$ & $0.5657^{*}$ & -0.1712 & 1.0000 & & & & & & & \\
\hline yieldKg_ha & $0.7325^{* *}$ & $0.3176^{*}$ & 0.0834 & $0.2619^{*}$ & 0.1343 & 1.0000 & & & & & & \\
\hline Nleaf6WAS & -0.0867 & 0.0361 & 0.1533 & 0.037 & $0.2189^{*}$ & -0.058 & 1.0000 & & & & & \\
\hline Nbrnch6WAS & $0.2673^{*}$ & 0.0241 & -0.149 & $0.4222^{*}$ & -0.1253 & $0.3806^{*}$ & $0.2294^{*}$ & 1.0000 & & & & \\
\hline Lghtinter6WAS & $0.2491^{*}$ & $-0.2062^{*}$ & -0.1144 & $-0.2956^{*}$ & $-0.2348^{*}$ & $-0.3385^{*}$ & -0.1239 & $-0.4482^{*}$ & 1.0000 & & & \\
\hline Larea4WAS & $0.3797^{*}$ & 0.1881 & $0.3111^{*}$ & $0.2631^{*}$ & $0.2714^{*}$ & $0.4241^{*}$ & 0.1425 & $0.3155^{*}$ & $-0.2971^{*}$ & 1.0000 & & \\
\hline LAI6WAS & $0.3093^{*}$ & 0.0568 & -0.0338 & $0.324^{*}$ & -0.0916 & $0.4176^{*}$ & 0.0088 & $0.5695^{*}$ & $-0.383^{*}$ & $0.2767^{*}$ & 1.0000 & \\
\hline Fodderkgha & $0.2794^{*}$ & -0.0244 & -0.1217 & $0.7794^{* *}$ & -0.0826 & $0.3614^{*}$ & 0.0724 & $0.6307^{*}$ & $-0.4101^{*}$ & $0.351^{*}$ & $0.4492^{*}$ & 1.0000 \\
\hline
\end{tabular}

Key: Yld-Yield, Fdy-Fodder yield, 100sw-100seed-wt, Podwt-Pod weight, Dry fodder, N/leaf6WAS- Number of leaf6WAS, N/brnch6WAS-

Number of branch6WAS, Lghtinter6WAS-Light interception6WAS, Xphyll6WAS-Chlorophyll6WAS, Stomaidx6WAS-Stomata index6WAS,

Larea4WAS-Leaf area4WAS and Lai6WAS- Leaf area index6WAS

Key : * Indicates significance at $5 \%$

“ $\quad:{ }^{* *}$ Indicates highly significance at $1 \%$

“ : + +Ve Correlations

“ : - -Ve Correlations 


\section{Special Conference Edition, November, 2018}

\section{DISCUSSION}

Cowpea growth seems to be inhibited if canopy was too dense and this may result in more light being wasted. In the field studies mean cowpea yield in 2015 ranged from $0-2150 \mathrm{~kg} / \mathrm{ha}$ at BUK farm and $0-1039 \mathrm{~kg} / \mathrm{ha}$ at Minjibir and cowpea grain yield in 2016 also ranged from $0-497 \mathrm{~kg} / \mathrm{ha}$ at BUK and $0-430 \mathrm{~kg} / \mathrm{ha}$ at Minjibir. The values were far above or below the cowpea grain yield of $1540 \mathrm{~kg} / \mathrm{ha}$ reported by Zoumana (2012). Sorghum yields were higher in 2016 at Minjibir compared with 2015 trial at BUK, reflecting the effect of the higher rainfall received in 2016. In both years of intercropped field experiment all the cowpea varieties had higher grain yield except IT89KD-288 which was late variety type, but lower fodder yields in 2016 compared with 2015. The low grain yield in 2016 could be attributed to heavy insect pests damage of cowpea flower and pods, despite the three insecticide spray regime which appeared inadequate. It is well known that moist and humid conditions that characterize seasons with high rainfall support heavy insect population and damage on cowpea. However, the higher grain yield in 2015 could be due to the even distribution of rainfall with peak in August when moisture was critical for flower and pod setting and seed yield (Sangakkara, 1990). However, in 2016 at BUK farm rainfall peaked in August (238.4mm), while the amount recorded in august at Minjibir 2015 season $(197.322 \mathrm{~mm}$ ) was lower than Minjibir 2016 (200.8mm). The high cowpea yield in 2015 could be associated with the drought tolerance characteristics of some of the varieties developed by IITA for Sudan and Sahel zones (Ntare et, al 1989). Variety IT99K- 573-1-1 had superior grain yield at both BUK and Minjibir

\section{REFERENCES}

Innis, D.Q. (2000). Intercropping and Scientific Basis of Traditional Agriculture. Intermediate Intercropping and its Advantages.Vol.3 NO 6. PP.112-114

Ntare, B.R. (1989). Cowpea genotypes for intercropping with pearl millet in a SudanoSahelian Environment. In Towards production technologies for maize and cowpea in

Rao M. R. and Willey R. W. (1983): Effect of Genotype on cereal /pegion pea intercropping on the ultisols of the semi Arid Tropics of India. Experimental Agriculture Vol. 19 No.5. PP67-78.

Sangagakara U.R., (1990). Response of selected legume comparison crops to irrigation across the period of study and this could be due to its medium maturing status and may be to its drought tolerance habit. These tallies with Rao and Willey (1983) that soy bean variety does not have significant effect on the yield of component crops but those differences in maturity time and growth habit of the components crops are important determinants of productivity under intercropping systems.

\section{CONCLUSION}

It could be concluded from these studies that under the traditional 1:1 cereal-cowpea of the Sudan savanna, the productivity of sorghum/cowpea intercrops were favorable by using early and medium maturing cowpea varieties. The studies indicated intercropping sorghum with medium maturing cowpea varieties IT99K-573-1-1 and IT98K-131-1 gave the highest grain yield. However, the late maturing varietyIT89KD-288 had the lowest grain yield and is considered to be susceptible to shading. Cowpea grain yields and intercrop productivity were superior at $2 \mathrm{~S}: 2 \mathrm{C}$ over $1 \mathrm{~S}: 1 \mathrm{C}$ and within mixed row arrangements. In view of the low fertility status of savanna soils and the importance of livestock in the farming system, the $2 \mathrm{C}: 2 \mathrm{~S}$ and sole cereal/cowpea holds great potential for improving the soil fertility and providing sufficient fodder for improved crop-livestock integrated systems in the Sudan savanna. The correlation coefficient in the combined studies of 2015 and 2016 showed that positive and negative correlations on the growth and yield traits as well as significant and highly significant difference on the characters studied like the number of branches which had significant effect on the grain yield and 100-seed weight among others.

frequencies - agricultural water management 17: 257 - 263.

Steindler C, Matteucci A, Sessa G, Weimar T, Ohgishi M, Aoyama T, Morelli G, Ruberti I. (2007) Shade avoidance responses are mediated by the ATHB-2 HD-Zip protein, a negative regulator of gene expression. Development 126: 4235-4245.

Zoumana K. (2012). Effect of cropping system and cowpea variety on symbiotic potential and yield of cowpea (vigina ungunculata L.walf) and pearl millet (Pennisetum glaucoma L.) $\mathrm{n}$ the sudano - sahelian zone of Mali. International Journal of Agronomy volume article ID 76139. 